\title{
The Structure and Function of Healing And Charm Spells
}

\author{
Andri Asmara \\ Universitas PGRI Palembang \\ andreasmara1010@gmail.com \\ Yessi Fitriani \\ Universitas PGRI Palembang \\ yessifitriani260@yahoo.co.id \\ Arif Ardiansyah \\ Universitas PGRI Palembang \\ arifacong@gmail.com
}

\begin{abstract}
This study aimed to determine the structure and function of healing and charm spells in Makarti Jaya village, Banyuasin District. This research used a qualitative descriptive method. The source of the data was 22 healing and charm spells which are taken from three informants. The data analysis used was content analysis. The results of this study indicated that not all spells mention a name component because some spells do not have a name element but still do not reduce the magical value of the spell, for a name is not a measure of whether the spell is effective. In the component of the opening greeting, The suggestions received in the analyzed spell are aimed at making the spell look pleasing. In the objective component, all spells have the same goal, which is to captivate the opposite sex. Whereas the closing element of all spells uses words from Arabic such as laillahailallah muhamadarasulullah. From the analysis of the seven healing spells and fifteen charm spells, it showed that the spell has a different structure and function according to the verse contained in the spell.
\end{abstract}

Keywords: Structure; context; function; spell

\section{A. Introduction}

One of the places in Nusantara that still uses spells in social life is Makarti Jaya Village, Banyuasin Regency. The spell in Makarti Jaya village is usually used for various purposes, for example, to treat sick people, prevent rain, and captivate the opposite sex. Spell is one of the speaking parts that can be used to express the words (Syafryadin, et al. 2019; Syafryadin, 2020; Syafryadin, et al. 2020). In this research, what will be discussed or examined are healing and charm spells. Charm spells are one of the techniques that are believed to have the power to conquer and captivate women's hearts. As a form of oral literature, the spell has cultural value. The spell is old poetry and old poetry is part of the Indonesian language. Old poetry can be lost if not developed. If $\mathrm{t}$ goes extinct then one Available at https://ejournal.karinosseff.org/index.php/iadila/ 
literary culture will be lost. Through literary works, the author conveys their views on life around them. Therefore appreciating literary works means trying to find the values of life that are reflected in literary works (Febriani, et al. 2020; Handayani, et al. 2020).

Many values of life are found in the literary work. Literature is a cultural product so that literature cannot be separated from human existence because it tells the life of society itself. In this study, the authors found problems, such as day by day there is a less and less public interest in learning the use of spells, the speakers or owners of the spell are also elderly and some have passed away. This is what encouraged the writer to conduct research in order to preserve the wealth of literature in the Makarti Jaya village, Makarti Jaya District, Banyuasin Regency.

The researcher was interested in researching healing spells and charm spells because these spells are most widely used in the village of Makarti Jaya and the researcher also saw the structure and function of these spells as interesting both in terms of their content and function. For example, if other spells, such as rain repellent spell is only used when we want to prevent rain when people have a wedding party and don't want it to rain, so it can be ascertained that the rain repellent spell is spoken and this spell is not used by the public all the time. Another case with charm spells and healing spells, this spell is commonly used by teenagers, parents, for treatment or not yet able to match, to captivate the opposite sex, as well as a wife or husband who wants to captivate her partner so that the relationship becomes more harmonious so that this spell is often used by local people in everyday life and can be used to treat an illness.

This fact is evidenced by its persistence in the village even though the interest of the community, especially teenagers, to study it has decreased, This is due to the progress of the times and increasingly sophisticated technology, as well as the loss of belief in healing spells and spells that captivate the hearts of the people towards the power of these spells. The composition of words based on poetry such as rhyme, rhythm, which is considered to contain other magical powers. The spell can contain a challenge or a curse against a magical power, and can contain inducements for supernatural powers, and can contain persuasion so that the magical power does not harm. Spell also means incantation, an old literary product composed in the form of rhythmic language, and uses a choice of words that are considered powerful and contain supernatural powers. The spell can only be spoken by the handler, Datuk, shaman 
in typical ways to get power from gods or other creatures, persuading or casting out evil spirits, and healing the sick.

Based on the description above, the researcher needs to analyze the structure and function of healing and charm spells in Makarti Jaya Village, Makarti Jaya District, Banyuasin Regency. Through structure and function analysis, we can find the elements and functions of oral literature contained in spells because the meaning in oral literature cannot be seen before understanding the elements first.

\section{B. Method}

The method used in this research was a qualitative method with content analysis techniques. Sugiyono (2012) stated that descriptive qualitative is one of qualitative research that explores the phenomenon. The object of this research was the structure and function of healing and charm spells in Makarti Jaya Village, Makarti Jaya District, Banyuasin Regency. Data source of this research were taken from oral literature of healing and charm spells from informants in Makarti Village, Makarti Jaya District, Banyuasin Regency. Purposive sampling was employed by the researcher in this study. Techniques of data collection were observating, recording, note taking and interviewing.

Furthermore, the data were analysed by using content analysis. Content analysis aimed to know or express, understand, and get the role of the literature. The important aspect in content analysis was content or meaning of the literature (Endraswara, 2013:160-161).

\section{Results and Discussion}

The data of this research were the spells obtained from 3 respondents which generally consists of 2 types of spells, namely healing spells and charm spells. There are 2 types of healing spells, namely (1) sangkal putung; (2) jolo sutro; and the charm spell consists of 2 spells, namely (1) ajian arjuno sukma; (2) ajian jaran goyang;

In the analysis, the data obtained from the respondents were codified as follows.

1. HS-1 and CS-1 (means healing spell and charm spell from respondent 1): Gunanto

2. HS-2 and CS-2 (means healing spell and charm spell from respondent 2): Sumolangkir

3. HS-3 and CS-3 (means healing spell and charm spell from responden3): Purwanto. The following are the four spells obtained from respondents or informants: 
1. Gunanto (HS-1 = 1, CS-1 = 1) :

a. Healing Spell (HS): Sangkal Putung,

b. Charm Spell (CH): Sukma Kawin Batin

2. Sumolangkir (HS-2 =3, CS-2 =7) :

a. Healing Spell (HS): Ajian Siti Hawa

b. Charm Spell (CH): Aji Arjuno Sukmo.

3. Purwanto (MPP-3 = 1, MPHP-3 = 4) :

a. Healing Spell (HS): Jolo Sutro

b. Charm Spell $(\mathrm{CH})$ : Ajian Macan Siliwangi.

The following is the data obtained in the study.

A. Gunanto's Healing Spell (HS-1) which includes the following types of spells:

\section{Sangkal Putung}

\section{Bissmilahirohmanirohim}

Kunfayakun tumtum balung podo balung

tumtum otot podo otot

tumtum daging podo daging

tumtum bayu podo bayu

tumtum sum-sum podo sum-sum

tumtum ketiban iduku putih

adem resep saking kersane allah

panas mawah-mawah

ketiban iduku putih

adem resep saking kersane allah

lailahaillallah muhamadrosullullah

cipto mati, roso mati, roso ilang, (inhale three times)

lebur kang ajur lailahailallah

nyanyikan sopo ganggu jahil karo aku

hiyo iku satune allahhu allah (inhale three times)

which means:

\section{Bissmillahirohmanirohim}

Be! Then it be

bone with bone

muscle with muscle

meat with meat

wind with wind

love with love

marrow with marrow

got hit by my white saliva

be at peace from Allah

there is no god but Allah, the prophet Muhammad is the messenger of Allah

Available at https://ejournal.karinosseff.org/index.php/jadila/ 
creates death, numbness, pain goes away (inhale $3 \mathrm{x}$ )

melts and crumbles

there is no god but Allah

sing who's bothering being rascal to me

it is only one from Allah (inhale $3 x$ )

Steps: drink zam-zam water while speaking this spell, read 10 times then rub the saliva on the broken part.

The analysis:

The name sangkal putung according to the story was used in the days of the kingdoms which was used to treat soldiers who had fracture problems.

a. In the opening greeting there is the word bissmillahirohmanirohim which is taken to strengthen the suggestion of this spell to make it more effective.

b. In the first line, in the word kun fayakun tumtum balung podo balung (Be! Then it be, bone with bone) it is intended that the broken bones are reconnected because the bones are connected to the bones.

c. In the second line, the word tum tum daging podo daging (meat with meat) is almost the same as the first line, so that the cut meat can heal or be put back together.

d. In the third line, the word tum tum bayu podo bayu (wind with wind) is intended so that the wind carries a message to the jinn or ancestral spirits to grant the wishes of the speaker.

e. In the fourth line, the word tum tum sum-sum podo sum-sum is meant for the spell to function for the problematic bone (broken).

f. In the fifth line, in the word tum tum ketiban iduku putih (got hit by my white saliva) is meant to be a medium because of the spell that is pronounced so that it becomes effective.

g. In the sixth line, in the word adem resep saking kersane Allah (be at peace from Allah) is intended so that the spell is approved by the Almighty.

h. In the seventh line, in the word laillahailallah muhamadarasullullah (there is no god but Allah) intended to acknowledge the blessing of the prophet Muhammad so that the spell becomes effective. 
i. In the eighth line, in the word cipto mati, roso mati, roso ilang (creates death, numbness, pain goes away) intended so that the purpose of using the spell can be achieved so that the speaker no longer feels pain.

j. In the ninth line, in the word lebur kang ajur laillahaillallah (melts and crumbles) it is meant that the pain suffered by speakers can be immediately cured with the blessing of the Almighty.

$\mathrm{k}$. Inthe tenth line, in the word nyanyikan sopo ganggu jahil karo aku (n sing who's bothering being rascal to me) intended so that safety accompanies the speakers so that in the future the problem does not occur again.

1. in the eleventh line, in the word hiyo iku satune Allah (it is only one from Allah) it means that all healing comes only from God.

a. The structure of the spell

1) The first element of the spell's name is Sangkal putung if it is translated into Indonesian, it means connecting the bones. This spell is spoke after doing the play of drinking zam-zam water, while speaking this spell as much as 10 times then saliva is rubbed on to the broken part.

2) The elements of the opening greetings contained in the spell are: the words adopted from Arabic, bissmillahirohmaniroh which means by saying the name of Allah who is all-gracious and most merciful. So before reciting the spell the speaker says the greeting first and then enters the spell recitation, the goal is that the spell works when pronounced.

3) The element of suggestion: contained in the sentence creates death, numbness, pain disappears with a high intonation, giving rise to the power of suggestion to the speaker, a combination of vowel sounds (asonance): a, e, i, o, u; voiced consonants (voiced): t, $\mathrm{g}, \mathrm{h}$; liquid sounds: $\mathrm{r}, 1$ and nasal sounds: $\mathrm{m}, \mathrm{n}, \mathrm{ng}$, ny make melodious and rhythmic sounds. The sentence is found in the 12th stanza the speaker suggests that the pain will be relieved by reciting this spell. 
4) The element of the goal is also contained in the sentence creates death, numbness, pain disappears which is found in verse 12 which aims to make the pain experienced by the speaker disappear and immediately recover from his illness.

5) The closing element contained in the sentence is only one from Allah, which is in the last stanza which is the reinforcement of the spell spoken by the speaker..

\section{b. The Function of The Spell}

The function found in this spell is for the treatment of fractures. The function relates to the use of spells in terms of the text or the spell itself as oral literature. The function analysis data is described based on theory (Dananjaya, 2014: 30), namely, the function of oral literature as a projection system or a means of validating cultural institutions, and as an educational tool. The following is an analysis of the MP-SP function as seen from the sentences Cipto Mati, Roso Mati, Roso Ilang (creates death, numbness, pain disappears) (inhale three times). This is what encourages the speech community to believe in the healing spell. The request is addressed to the jinn or ancestral spirits. They hope that by speaking the spell, their wishes and hopes will come true and come true. In the implementation of healing spell there is no requirement in the form of offerings.

\section{B. Charm Spell (CH-1)}

\section{Sukma Kawin Batin}

Bissmillahirohmanirohim

Sukma rasa sukmu ranting rantang ranting

Dulor papat lema badan

Jabroil, mikail, isrofil, izroil, pakabin aki

Sukmo sengko karo (crush's name)

Seumpama tedung teko seko atine

Angin sinabung bengi (mention the crush's name)

Lamun getak dangiding aki

Bhan se nemonin ah sengko bhan se aropa

Jabang bayine (crush's name)

Lailahailallah muhamadarasulullah

Means:

By saying the name of Allah, the most merciful

Available at https://ejournal.karinosseff.org/index.php/jadila/ 
Your heart feels like a branch

The four are weak

Jabroil, mikail, isrofil, izroil

Her body with (crush's name)

I wish the pressure came from her heart that night

If the glass is dangle the battery

Prohibition met bypassed

prospective baby (crush's name)

There is no God but Allah.

The steps: reading the spell for 30 days after praying, mentioning the name of the target person.

The Analysis:

In the name of the spell sukma kawin batin contains the meaning of marrying the mind of the target person.

1) In the first line, bismillahirohmaniirohim is intended to make the spell effective because it has the blessing of God.

2) In the second line, your heart feels like a branch is defined by the heart of the person being addressed not yet having one goal, the speaker expects to make his branched heart become one.

3) third array, the four are weak, jibril, mikail, isrofil, izroil which is defined as nothing that can match the spell even though four angels even though this means that the power of this spell is very powerful.

4) Then in the fourth line, that is if the pressure comes on her that night, it is defined as the power of the spell for the target person carried out at night.

5) the fifth line, if the glass dangles the battery, the prohibition met bypassed, which means things that are impossible to achieve with this spell.

6) in the last line the prospective baby (the name of the target person) is defined as the target person, still innocent like a baby will become love and love for the speaker.

1) The Structure of The Spell 
a) The element of the name of the third spell is Sukma kawin batin, which means that if this spell is read the target will love and it is difficult to turn away from other people.

b) The elements of the opening greetings contained in this third spell are words adopted from Arabic, namely bissmillahirohmanirohim which when means by saying the name of allah who is all-compassionate and most merciful. So, before speaking the spell the speaker says the opening greeting first and then enters the spell reading. The goal is that the spell is effective when spoken.

c) The element of suggestion to this spell is found in the seventh stanza lamun getak dangiding aki with a high intonation so that it raises the suggestion of the speaker, a combination of vowel sounds (assonance): a, e, i, o, u; voiced consonant sounds (voiced): s, $\mathrm{k}, \mathrm{b}$, liquid sounds: $\mathrm{r}, \mathrm{l}$, and nasal sounds: $\mathrm{m}, \mathrm{n}, \mathrm{ng}$, ny give rise to melodious and rhythmic sounds. People who read this spell suggest that they grip the feeling of the person who is being read the spell as if only he can change human feelings.

d) The elements of the goal are found in the first and second verse which is sukma rasa sukmu rantin rantang ranting dan dulur papat lemah badan meaning that people who read this spell will suggest that no matter how difficult it is to conquer the target person it will be easier if you use this spell. The element of the goal is in the first and second stanzas, the same as the suggestion element earlier, the goal is that if this spell is read the person being targeted will easily love the speaker.

e) The closing element in this spell uses Arabic as evidenced by the final line of this spell, namely laillahailallah muhamadorasulullah which means there is no god but Allah.

2). The Function of The Spell

The function found in this spell is the function of captivating a woman's heart or to make the relationship between our partners stronger and not easily tempted by other parties that can damage the relationship. This spell analysis can be seen from the sentence lamun getak dangiding akibate seng nemonin ah...sengko bhan se aropa jabang bayine (jeneng wong seng dituju) laillahaillallah. This is what encourages the speech community to believe in the healing spell, the request will be granted. 
The request is addressed to the jinn or ancestral spirits. They hope that by saying the spell, their wishes and hopes will come true. In the implementation of a charm spell, some plays or conditions must be done, which can only be done after reading the spell for 30 days and praying hajad while mentioning the intended name.

\section{A. Healing Spell Sumolangkir (HS-2)}

\section{Ajian Siti Hawa}

Aku ngerti ngendi sampean teko iso ngenteni getih haid Siti Hawa langit bakal dadi panggonanmu medot sambungan ngangkut sandi guyu kabul minang ka doa guru kulo mustajab kanggo kulo nawarke ing kulit ora pakaryan Allah tawar Muhamad ngapusi raja nabi kanggo Lailahaillallah

Which means:

I know where you came from can wait for Eve's blood the sky will be your place disconnected lifting with a laugh please grant the prayer of my effective teacher to be medicine in the skin not from Allah

Muhammad's medicine deceived the king of all the prophets with laillahailallah

Steps: prepare plain water to read 3 times at night before going to bed then apply it to the sore, the water is given garlic.

The Analysis:

The name Ajian Siti Hawa according to the story is taken from the story the wife of the prophet Adam, namely Siti Hawa (Eve), the ancestor of all humans on this earth.

a. In the first line, ngerti ngendi sampean teko it is meant that speakers know where the origin of this disease came from.

b. in the second line, iso ngenteni getih haid Siti Hawa, it means that speakers have had strength for a long time. 
c. in the third line, langit bakal dadi panggonanmu, it means that we all share the same origin of the creator and will return to the creator.

d. in the fourth line, medot sambungan ngangkut sandi guyu, it means that lifting the child's body makes him laugh.

e. in the fifth line, kabul minangka doa guru kulo mustajab kanggo kulo nawarke, it means the speaker's hope that his prayer will be answered by the almighty.

f. in the sixth line, ing kulit ora pakaryan Allah, that is, all kinds of medicines that are not from Allah will not reach us.

g. in the seventh line, tawar muhamad ngapusi raja nabi kanggo laillahailallah, it means that the medicine used according to the prophet's sunnah is the most effective medicine through laillahailallah.

1) The Structure of The Spell

a) The name element of the third spell is: Ajian Siti Hawa if interpreted into Indonesian, it is a spell from the ancestors of mankind Siti Hawa (Eve). This spell is read out after doing the play of drinking water at night while reading this spell 3 times at night before going to bed then rubbed on to the part that hurts.

b) There is no element of the greeting in this spell.

c) The element of suggestion: contained in the sentence ing kulit ora pakaryan Allah, with a high intonation so that it raises the suggestion of the speaker, a combination of vowel sounds (assonance): a, e, i, o, u; voiced consonants (voiced): o, h; liquid sounds: r, 1, and nasal sounds: m, n, ng, ny causing melodious and rhythmic sounds found in verse 6, speakers suggest that whatever medicine does not come because Allah will not be able to cure any disease.

d) The element of the goal is contained in the sentence kabul minangka doa guru kulo mustajab kanggo gusti Allah contained in verse 5 which aims to make this spell a cure for the speaker's illness.

e) There is no closing element in this spell.

Available at https://ejournal.karinosseff.org/index.php/jadila/ 
2) The Function of The Spell

The function found in this spell is the function of treating skin diseases from minor skin diseases to severe skin diseases. Usually in the use of this spell, it is widely used by people who have skin problems that have not healed for a long time usually the result of magic or the deeds of jinn or evil spirits. Basically, speakers want a cure for the pain suffered by the person experiencing this, this can be seen from the sentence kabul minangka doa guru kulo mustajab kanggo kulo nawarke. This is what encourages the speech community to believe in a healing spell.

The request is addressed to the jinn or ancestral spirits. They hope that by saying the spell, their wishes and hopes will come true. In implementing the healing spell, there are requirements such as offering a glass of water with 7 colors of flowers and garlic, 7 colored flowers are a symbol of the 7 treatments for skin diseases while garlic is an antidote from bacterial toxins. These offerings are a form of respect for the speech community of the jinn or ancestral spirits.

\section{B. Sumolangkir's Charm Spell (CS-2)}

\section{Aji Arjuno Sukmo}

Bissmillahirohamnirohim

Salam, salam, salam sang sejati

Hanembah ambuko wiworo jati

Sejatining sukmo lanang kamajaya pinindho

Angrasuk ing badan mami

Bagus sinawang kamitenggengan

Ingkang amriksani pasuryaningsun

Yo iki sing lanang jati, arjuno kasmaran

Ingsun mandeng tuwuh tresno

Ingsun mesem kapikut asmoro

Pasrah ingsun bayong ing gatuloyo

Yo jabang bayine...... (sebut jenenge seng dituju)

Pasrah jiwo rogo ndeprok badondo asmoro ing saliraningwang

Which means:

\section{Bissmillahirohmanirohim}

Greetings, greetings, true greetings

First is human, last is body, 
either the body that shows on my face

When arjuna's son fell in love

With his love as a child in the world

Baby boy (say the name of the target)

Resigning from the soul to place on bare ground in the rain.

The steps: white fast for 12 days, then take a shower at midnight during the last fast while reading the spell

The Analysis:

1) In the first line in the meaning of this spell there is the word, first is human, the last is the body which means the target person will feel it through his body.

2) in the second line there is the word, either the body that shows on my face means that the person being targeted is the person he is seeing.

3) in the third line When arjuna's son fell in love With his love as a child in the world can be interpreted as The chanter with a manly figure like Arjuna in the story, falls in love with a special person.

4) in the fourth line The chanter with a manly figure like Arjuna in the story, falls in love with a special person, intended to bring the soul of the person who is intended to enter into his heart. Links in all lines.

\section{1) The Structure of The Spell}

a) The name element of the first spell is Aji Arjuno Sukmo which when translated means the soul of arjuna. When the spell is read, the target person will vail and love the reader of the spell, its function is to give the imagination strengthening the soul of an arjuna.

b) The elements of the opening greetings contained in this spell are words adopted from Arabic, bissmillahirohmanirohim, which means by saying the name of Allah who is allAvailable at https://ejournal.karinosseff.org/index.php/iadila/ 
compassionate and most merciful. So before reading the spell the speaker says the opening greeting first and then enters the spell reading, the goal is that the spell is effective when spoken, its function is to strengthen the relationship with the almighty god.

c) The element of suggestion in this second spell is found in the 3rd and 4th line, sejatining sukmo lanang kamajaya pinindho, and, angrasuk ing badan mami with a firm flat intonation so as to give rise to suggestion to the speaker, a combination of vowel sounds (asonance): a, e, i, o, u; voiced consonant sounds (voiced): m, s, h, g liquid sounds: r, 1 and nasal sounds: m, $\mathrm{n}$, ng, ny make melodious and rhythmic sounds. The speaker suggests that the target will love him, its function is to influence one's imagination.

d) The goal element is found in line 12, pasrah jiwo rogo ndeprok badondo asmoro that is, the spell reader aims so that the target will open his heart and then love him, its function is to process the meaning of the spell array.

e) In this spell there is no closing component/element.

2) The Function of The spell

The function found in this spell is to captivate the opposite sex who is hard to get love for or tie up a partner who is bored or starts off to another heart. Analysis of the function of the CS-AAS can be seen from the sentence, pasrah jiwo rogo ndeprok badondo asmoro ing salira ning wang. This is what encourages the speech community to believe that by saying this charm spell will function according to the speaker's request. In the implementation of a charm spell, there are plays or conditions that must be done, such as fasting mutih 12 days then taking a shower at midnight while reading the spell.

\section{Conclusion}

The spell is believed by the people of Makarti Jaya Village to have supernatural powers, from this belief that spells have different functions according to the speaker's goals. Apart from that the spell also has a structure and meaning which includes name element, opening element, objective element, closing element, context, and function. Based on the research results, not all spells mention the name component, because there are some spells 
which do not have a name element but still do not reduce the magical value of the spell, for a name is not a measure of whether the spell is effective.

In the component of the opening greeting, The suggestions received in the analyzed spell are aimed at making the spell look pleasing. In the objective component all spells have the same goal, namely to captivate the opposite sex. While the closing element of all spells uses words from Arabic such as laillahailallah muhamadarasulullah. From the analysis of seven healing spells and fifteen charm spells, this shows that the spell has a different structure, context, and function according to the verse contained in the spell. In this study, it can be concluded that all the spells obtained from 3 respondents or informants include:

1. Gunanto (HS-1 = 1, CS-1 = 1) :

a. Healing Spell (HS) : Sangkal Putung

b. Charm Spell (CS) : Sukma Kawin Batin

2. Sumolangkir (HS-2 = 1, CS-2 = 1):

a. Healing Spell (HS): Ajian Siti Hawa, Aji Bocah Siliwangi, Sapeh Anak.

b. Charm Spell (CS): Aji Arjuno Sukmo

Generally used by teenagers and adults who want to cure diseases and captivate the opposite sex. This spell can be done by anyone. For the Javanese people in the village of Makarti Jaya, these spells should not be uttered out loud, Learning this spell also has to be in a low voice and with an older person for the spell to be effective when recited.

Based on the research that the researcher has done, the contribution that can be given in the world of education, especially in spells, which can become a cultural treasure, and can add insight and cultural heritage which when used in schools can be information material in the field of old literature, namely old poetry or spells.

\section{References}

Amir, A. (2013). Sastra lisan Indonesia. Yogyakarta: Andi

Arikunto, S. (2013). Prosedur penelitian suatu pendekatan praktik. Jakarta:Rineka Cipta.

Dananjaya, J. (2014). Foklor Indonesia : Ilmu gosip, dongeng, dan lain-lain. Jakarta: Balai Pustaka.

Emzir, R.S. (2017). Teori dan pengajaran sastra. Depok: Rajagrafindo Persada.

Febriani, R. B. Satinem., Nurnaningsih., Haryani., Syafryadin, Noermanzah.(2020). Conveying an author's intention to efl readers: The meaning of "The Road Not Taken" by Robert Frost. International Journal of Innovation, Creativity and Change (IJICC), 13(4), 172.

Available at https://ejournal.karinosseff.org/index.php/jadila/ 
Gunawan, I. (2013). Metode penelitian kualitatif, teori dan praktek. Jakarta: Bumi Aksara.

Handayani, S., Youlia, L., Febriani, R.B., Syafryadin, S. (2020). The use of digital literature in teaching reading narrative text. Journal Of English Teaching, Applied Linguistics And Literatures (JETALL). 3(2), 65-74.

Pradopo, R.D.(2017). Pengkajian puisi. Yogyakarta: Gadjah Mada Universitas Press.

Sugiyono. (2012). Metode penelitian kualitatif, kuantitatif dan mixed method. Jakarta: Rineka Cipta.

Syafryadin, H., \& Salniwati, A. R. A. P. Digital Storytelling Implementation for Enhancing Students' Speaking Ability in Various Text Genres. International Journal of Recent Technology and Engineering (IJRTE). 8(4), 3147-3151.

Syafryadin, S. (2020). Students' Strategies in Learning Speaking: Experience of Two Indonesian Schools. Vision: Journal for Language and Foreign Language Learning, 9(1), 33-46.

Syafryadin, S., Martina, F., \& Salniwati, S. (2020). Compensation strategies in speaking activities for non-English department students: poor and competent speakers. JEES (Journal of English Educators Society), 5(2), 109-116. 